\title{
Lélektani folyamatok és ezek következményei a szülök kapcsolatának felbomlása során
}

\section{VISONTAI-SZABÓ Katalin ${ }^{1}$}

\begin{abstract}
Napjainkban a házasságok és általában a párkapcsolatok bomlékonyabbak, mint valaha. Ennek következtében egyre több gyermek tapasztalja meg szülei kapcsolatának megszünését. A család szétesése mindenkit megvisel, rövid és hosszú távon is negatív hatást gyakorol a személyiségfejlődésre. A téma a társadalom jelentős részét érinti, így fontos, hogy tisztában legyünk azzal, hogy a kapcsolat megszúnése következtében milyen érzelmekkel és nehézségekkel kell megbirkózni. A tanulmány külön elemzi a gyermekek és a felnőttek, a fiúk és a lányok, valamint az egyes életkori csoportok érzelmi reakcióit, hiszen az átfedések ellenére jelentős eltérések tapasztalhatók.
\end{abstract}

Kulcsszavak: házasság felbontása, szülői felügyelet rendezése, kapcsolattartás, pszichológia, szülői elidegenítés, egyszülős család, mozaikcsalád, a gyermek jogai

\section{Új családformák a magyar társadalomban}

Magyarországon az 1970-es évek óta tartó trend, hogy a fiatalok körében egyre csökken a házasságkötések száma, a válások száma emellett nagyjából azonos szinten marad, ennek következtében ma már elmondhatjuk, hogy körülbelül minden második házasság válással végződik. A gazdasági, politikai és társadalmi változások következtében a családok hagyományosnak mondott szerkezete jelentősen átalakult. A korábban természetesnek tartott nagycsalád, ahol több generáció élt és dolgozott együtt, ma már egyáltalán nem jellemző - a legtipikusabbnak mondott együttélési forma jelenleg a nukleáris család és az egyszülős család. A nukleáris családokban egy szülőpár és gyermekei laknak együtt, ennek következtében nem számíthatnak a nagyszülők, testvérek segítségére. Az egyszülős családok nagy száma, ahol valamelyik szülő (tipikusan az anya) egyedül neveli gyermekeit, sok esetben csak egy statisztikai megtévesztés,

\footnotetext{
VISONTAI-SZABÓ Katalin dr., PhD, adjunktus, SZTE Állam- és Jogtudományi Kar, Munkajogi és Szociális Jogi Tanszék, Jogpszichológiai Kutatócsoport

Katalin VISONTAI-SZABÓ PhD, senior lecturer, University of Szeged, Faculty of Law, Department of Labour Law and Social Security, Legal Psychology Research Group

orcid.org/0000-0002-3295-5675, visontai@juris.u-szeged.hu
} 
hiszen ebbe a körbe sorolhatók azok a családok is, ahol a szülők nem házasságban, hanem élettársi kapcsolatban élnek. ${ }^{2}$

Szintén egyre elterjedtebb forma az úgynevezett mozaikcsalád (vagy patchwork család), amelynek alapja egy férfi és egy nő kapcsolata, amennyiben már mindketten túl vannak egy párkapcsolaton, amelyből gyermek is származott. Ebben a családban összetartozik tehát az anya és gyermeke, az apa és gyermeke, valamint elképzelhető, hogy a párnak közös gyermeke is születik, így féltestvérek, testvérek és mostohatestvérek élnek egy fedél alatt. ${ }^{3}$ A vegyes összetételű családoknak számtalan előnye lehet, például a gyermekek megtanulnak másokhoz alkalmazkodni, egy teljes, nem pedig csonka családban nőhetnek fel, valódi szeretetkapcsolat alakulhat ki a családtagok között. Azonban nehézségek is adódhatnak az ilyenfajta együttélésből, hiszen nem szabad elfelejteni, hogy a családban nevelkedő gyerekeknek van egy másik szülője is, aki nem biztos, hogy kellő elfogadással viszonyul a tágabb család új tagjaihoz és ezzel rendkívüli módon meg tudja keseríteni a hozzátartozói életét. Problémát okozhat továbbá, hogy a mozaikcsalád határai nem egyértelműek, ${ }^{4}$ hiszen nem egészen tisztázott a hétvégi kapcsolattartásra érkező gyermekek helye, szerepe a rendszerben, valamint az sem, hogy a tágabb család miképp viszonyuljon a gyerekekhez. Gondoljunk csak a nagyszülőkre, akik nem tudnak nem különbséget tenni a vér szerinti unokák és a „fiam új élettársának előző házasságából származó gyerekei” között. A mozaikcsalád férfi tagjait továbbá megviselheti, hogy nap mint nap egy számukra idegen gyermekről gondoskodnak, miközben saját gyermekeiket egy másik férfi neveli a volt házastársukkal. ${ }^{5}$

Napjainkban még nem nevezhető általánosnak, de egyre nagyobb népszerúségre tesz szert a „mingli” életforma, amelyben a szerelmesek elkötelezett párkapcsolatot alakítanak ki egymással, azonban nem költöznek össze és közös gyermekük sem születik. Ennek a lazább, úgynevezett látogató partnerkapcsolatnak (Living Apart Together, röviden: LAT ${ }^{6}$ általában az az oka, hogy a felek valamelyike már túl van egy csalódást okozó párkapcsolaton, és nem szeretné a korábbi hibákat ismételten elkövetni. Elképzelhető az is, hogy nem szeretnék a gyermekeik életét azzal megzavarni, hogy egy „új aput” vagy „új anyut” hoznak a házhoz, illetve az is az okok között szerepelhet, hogy egymástól távol élnek, és egyikük sem szeretné feladni a korábban megszokott életét, jól bevált állását, ezért inkább csak hétvégenként és ünnepnapokon találkoznak egymással.

Szociálpszichológiai szempontból érdekes kérdések például, hogy miért élnek napjainkban a párok szívesebben élettársi kapcsolatban házasság helyett? Illetve miért nem vállalnak több gyermeket?

Az első kérdésre nemcsak a pszichológusok, hanem a szociológusok és a statisztikusok is évek óta keresik a választ. Míg az 1990-es évekig egyértelmúen csak az alacso-

\footnotetext{
Somlai (2013) 159.

Fischer (2005) 8.

Fischer (2005) 14

Fischer (2005) 101.

Somlai (2013) 153.
} 
nyabb státuszú, a társadalom alsóbb rétegeihez tartozó személyek, illetve az özvegyek választották ezt az életformát, ${ }^{7}$ ma már a társadalom minden szintjén és a fiatalok körében is népszerú, annak ellenére, hogy a statisztikai adatok tanúsága szerint lényegesen bomlékonyabb, mint a házasság. Egy átlagos házasság 12,5 évig tart, egy élettársi kapcsolat csak 6 évig. A törvényes együttélésekben több gyermek is születik. További nehézséget jelent, hogy a kapcsolat instabilitásából következően az élettársi kapcsolatokban született gyermekek sokkal fiatalabbak a szüleik kapcsolatának megszúnésekor, mint a házasságban született gyermekek.

A kérdés tehát az, hogy szemmel látható hátrányai ellenére miért választják mégis egyre többen a házasságkötés nélküli együttélést? Kézenfekvőnek látszik, hogy sokan azért nem akarnak megházasodni, mert csalódtak a házasság intézményében. A ma 20 és 40 év közötti korosztály - azok, akik potenciálisan abba a körbe tartoznak, hogy családot alapítanak - jelentős része gyermekként kénytelen volt elszenvedni szülei kapcsolatának felbomlását. Ebből azt a téves következtetést vonták le, hogy a házasság rossz dolog, amit érdemes elkerülni. ${ }^{8}$ Gyakran hallani a fiatalok szájából, hogy nem akarnak elválni, úgy mint azt a szüleik tették, ezért inkább nem kötnek házasságot. Való igaz, hogy ebben az esetben tényleg nem kell a házasságot felbontani, ezt valóban „megúszhatják”, azonban mi a garancia arra, hogy az élettársi kapcsolatuk nem fog zátonyra futni? Vagy azért akkor nem is kár? Szintén gyakori hivatkozás a fiatalok körében, hogy a házasság csak egy papír, aminek semmi jelentősége sincsen, és nekik semmi szükségük arra a papírra, ahhoz, hogy boldogok legyenek. Emögött valójában inkább egy erős félelem húzódik meg, sok fiatal nagyon tart az elköteleződéstől. Néhányan azért nem akarnak komolyabb kapcsolatba bonyolódni valakivel, mert abban bíznak, hogy hamarosan találnak valakit, aki jobban megfelel az elvárásaiknak, és ebben az esetben könnyebben tudnak továbblépni az új kapcsolatba. A lehetséges okok között érdemes megemlíteni a 21. századi szabadságkultuszt, azaz, hogy napjainkban a szabadságnak kiemelkedő jelentősége van a fiatalok életében, és ebben nem fér bele az, hogy „lekössék” magukat.

A második kérdés megválaszolása sem egyszerủbb, és szintén más tudományterületek képviselőit is megmozgatja, vajon miért születik egyre kevesebb gyermek hazánkban? A probléma rendkívül soktényezős, minket most csak a lélektani vetületei érdekelnek. A gyermekekre jellemző egocentrikus világkép miatt sok fiatal érezhette azt, hogy a szülei - legalább részben - miatta váltak el, így érthető, ha a jövő generációját meg akarják kímélni attól a sok rossz érzéstől, amiben részük volt, és úgy döntenek, hogy nem vállalnak gyermeket. ${ }^{9}$ Mindenképpen lényeges változásnak tekinthető, hogy a mai szülőknek sokkal nagyobb terheket kell vállalni, amikor gyermek érkezik a házhoz, vegyük például azt, hogy sokkal tovább tart a gyermek felnevelése, hiszen napjainkban egy 18 éves gyermek még egyáltalán nem önálló. Nehézséget okozhat az is, hogy a szülőknek sokkal több mindenről kell lemondani, mint korábban, amikor még

Somlai (2013) 151.

Bagdy et al. (2007) 116.

Zimbardo-Coulombe (2015) 94. 
nem állt rendelkezésre ilyen sokféle szórakozási lehetőség, valamint a karrierlehetőségek is sokkal korlátozottabbak voltak. A gyermekvállalási kedv ellen hat az, hogy a szülők nem igazán számíthatnak saját szüleik segítségére, mert távol élnek tőlük, mert még ők is aktívan dolgoznak, vagy épp ellenkezőleg, mert már nagyon idősek, vagy esetleg meg is haltak. Sok esetben azért nincsen segítség, mert az anya és az apa mindenkitől azt hallja, hogy egyedül is meg lehet ezt oldani, a gyengeség, tehetetlenség jele, ha segítséget kell kérni a felmenőktől, illetve sok családban a nagyszülők is elutasítják a segítségnyújtást, mert úgy érzik, hogy nekik most jött el az idő a pihenésre. Nem serkenti a gyermekvállalási kedvet az sem, hogy a statisztikai adatok tanúsága szerint egy jelenleg párkapcsolatban élő nőnek 50\% esélye van arra, hogy a megszületendő gyermeket majd egyedül kell felnevelnie. ${ }^{10}$

Egy, az Egyesült Államokban elvégzett kutatás tanúsága szerint az amerikai fiatal férfiak jelentős része számára egyáltalán nem vonzó a stabil, monogám párkapcsolat és az apai szerep. Ennek két oka lehet a kutatás vezetői szerint: egyrészt ezek a férfiak többnyire apa nélkül nőttek fel, így valójában nem is ismerik azokat a szerepeket, amelyeket elutasítanak. A másik ok lehet, hogy a szülei a széltől is óvták, mindent elintéztek helyette, minden lehetséges kudarctól megkímélték, így felnőtt korára valójában teljesen életképtelenné vált. Természetes, hogy az a fiatal, aki még 30 évesen is a szüleivel lakik, és nem képes magáról gondoskodni, nem igazán vágyik arra, hogy családfő legyen. ${ }^{11}$ Egy másik, szintén a tengerentúlon végzett kutatás a nők gyermekvállalási szokásai mögött megbújó okokat keresve azt találta, hogy a fiatal nők kimondva vagy kimondatlanul azt az üzenetet kapták az édesanyjuktól, hogy sokkal jobban járnak, ha a gyermekvállalás helyett a karrierépítésre koncentrálnak, hiszen a gyermek a szakmai siker és a boldog párkapcsolat legfőbb akadálya. ${ }^{12}$

Végül pedig nem szabad figyelmen kívül hagyni azt az okot sem, hogy a rövidebb ideig tartó, nem túl stabil párkapcsolatokban eleve kevesebb gyermek jön a világra. Sokan pedig egyszerűen csak kifutnak az időből a karrierépítés, illetve a tökéletes partner keresgélése közben. A megfelelő férj megtalálását tovább nehezíti, hogy napjainkban a felsőoktatásban több nő tanul, mint férfi, így hamarosan általánosnak lesz mondható, hogy a nők magasabb iskolai végzettséggel rendelkeznek, mint a férfiak. ${ }^{13}$

\section{A válás lélektana}

Amennyiben a házasság felbontása elkerülhetetlen, mindenképpen hasznos, ha tisztában vagyunk a válás folyamatában és azt követően jelentkező lelki jelenségekkel és nehézségekkel. A kapcsolat felbomlása mindkét fél számára veszteség, feldolgozása a gyászfolyamathoz hasonló. Álláspontunk szerint minden krízishelyzetből könnyebb kilábalni, ha az ember tisztában van az érzéseivel, azok kiváltó okaival, és tudja, hogy

\footnotetext{
Largo-Czernin (2011) 124.

Zimbardo-Coulombe (2015) 26-27.

Zimbardo-Coulombe (2015) 91.

Visontai-Szabó-Zakar (2014) 277.
} 
éppen mi zajlik benne. Érdemes külön-külön megvizsgálni, hogy a válás milyen hatással van a felnőttekre és a gyermekekre, hiszen életkorukból és érettségükből adódóan egészen másképp gondolkoznak és éreznek.

\section{A válás lélektani hatásai a gyermekekre nézve}

A válás a gyermek életét a legnagyobb körültekintéssel előkészített bontás esetében is megzavarja, hiszen bizonytalanságérzetet kelt benne. A gyermekek számára az érzelmi biztonságot a szülők jelentik, és ehhez az apára és az anyára is szükségük van, számukra a család egy megbonthatatlan egység. ${ }^{14}$ Amennyiben az egyik szülő kikerül a gyermek közvetlen környezetéből, az számára válságot idéz elő, és úrrá lesz rajta egy irracionális bưntudat, azaz azt hiszi, hogy az ő hibája, hogy a szülei kapcsolata tönkrement. Tekintettel arra, hogy a gyermek egész családban szeretne élni, bármelyik szülő hiánya kihat a személyiségfejlődésére, azaz egész életre szóló sebeket szerezhet. Amerikai kutatási eredmények szerint, amelyeket magyarországi vizsgálatok is megerősítettek, az elvált szülők gyermekei korábban kezdik a szexuális életet, később házasodnak, gyorsabban elválnak, és nem szívesen vállalnak gyermeket, amely nem csoda, hiszen azt a mintát kapták szüleiktől örökül, hogy a házasság egy rossz dolog, és minden konfliktus esetén a válás az egyetlen megoldás. ${ }^{15}$

Általánosságban a következő tüneteket válthatja ki a gyermekekben a szülők kapcsolatának felbomlása:

- általános nyugtalanság;

- evési kényszer (nyugtatásképpen);

- álmatlanság;

- ágybavizelés;

- magatartási problémák;

- pszichoszomatikus tünetek;

- szorongás;

- agresszív magatartás;

- harag, düh;

- szociális és érzelmi visszahúzódás;

- koncentrációs nehézségek;

- teljesítőképesség csökkenése. ${ }^{16}$

A gyerekek eltérően reagálnak a szülők válására az életkoruktól és a nemüktől függően. Egy dologban azonban nagyon hasonlítanak egymásra, fiúknak és lányoknak egyaránt szükségük van mind az anyai, mind az apai gondoskodásra, hiszen a szülőknek eltérő szerepe van a gyermek életében. Az anya a biztonságot, a szeretetet, a melegséget biz-

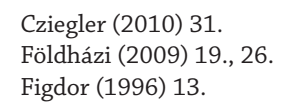


tosítja, az apa feladata pedig, hogy átadja a szabályokat, megtanítson a normakövetésre és arra, hogy elboldoguljunk a világban.

Ha a nemek szerint teszünk különbséget, a fiúknál a tipikus tünetek a következők:

- éjszakai felriadás;

- ágybavizelés;

- félénkség;

- idegesség;

- szóbeli vagy fizikai durvaság;

- romló iskolai teljesítmény.

Amennyiben a válás következtében a fiú életéből teljesen eltűnik az apa, annak igen komoly következményei lesznek, hiszen az anya nem képes a gyermek számára a férfias viselkedés modelljével szolgálni. ${ }^{17}$ Amerikai kutatások szerint, amennyiben egy fiú apa nélkül nő fel, nagyobb valószínűséggel fog tanulási nehézségekkel és viselkedési problémákkal küzdeni, hajlamosabb lesz a vandalizmusra és az erőszakra, nagyobb esélye van a bűnözői pályafutásra, a deviáns csoportokhoz való csatlakozásra és öngyilkosság elkövetésére. ${ }^{18}$ Ranschburg Jenő is hasonló véleményen volt, ő a mai magyar társadalmat apátlan társadalomnak nevezte. ${ }^{19}$

Philip Zimbardo neves amerikai szociálpszichológus, akinek a nevéhez köthető a híres stanfordi börtönkísérlet, régóta kutatja, hogy mi lehet az oka annak, hogy napjainkban a férfiak sokkal kevésbé férfiasak, és kevésbé sikeresek, mint korábban. A Nincs kapcsolat című művében a következő kérdésre keresi a választ: „Hová lettek a férfiak?” Álláspontja szerint a megváltozott gazdasági, társadalmi és technológiai környezetben, megfelelő apai minta hiányában a férfiaknak nem fejlődnek a társas készségeik, amelyre az életben való boldoguláshoz nagy szükségük lenne. ${ }^{20}$ Ennek oka, hogy túlságosan elmerülnek a virtuális térben, de a videójátékok és a pornófilmek okozta sikerélmények a valóságban nem elérhetőek. ${ }^{21}$

A lányok esetében a következő tünetekkel kell számolnunk:

- szomorúság;

- harag;

- pszichoszomatikus zavarok;

- fóbiás tünetek.

A lányok esetében is nehézséget okoz, ha az apa teljesen eltűnik az életükből. Ugyan a női szerepmintát megkapja, azonban ahhoz, hogy egy párkapcsolatban megtalálja a helyét, arra is szüksége lenne, hogy lássa miként müködik egy szerelmi kapcsolat, mit várhat el egymástól a férfi és a nő. A megfelelő példa hiányában az apa nélkül felnőtt lányok

\footnotetext{
Cziegler (2010) 35.

Dowling-Barnes (2001) 15.

Ranschburg (2005) 32-33.

Zimbardo-Coulombe (2015) 12-13.

1 Zimbardo-Coulombe (2015) 14-16.
} 
nagyobb valószínúséggel bonyolódnak korai szexuális kapcsolatokba, alakítanak ki szerelmi viszonyt náluk jóval idősebb férfiakkal, és lesznek alárendelődőek, valamint túlságosan odaadóak párkapcsolataikban. ${ }^{22}$ További nehézséget okoz, hogy a nemi és a szülői szerepek jelenleg erőteljes átalakuláson mennek keresztül, és ebben a folyamatban jelenleg ott tartunk, hogy a korábbi, hagyományosnak mondott pozíciók felbomlottak, hiszen a nők is magas iskolai végzettséget szereznek, jól keresnek, stabil egzisztenciát tudnak teremteni, illetve a férfiak sok esetben ugyanolyan odaadóan nevelik egyedül gyermekeiket, mint tették azt korábban a nők. A változás mindig jó dolog, hiszen ez a fejlődés mozgatórugója, egyelőre azonban csak azt érezzük, hogy nem tudjuk, hogy hol a helyünk, mi a feladatunk, mi a szerepünk, mert az új pozíciók még nem alakultak ki, így sok gyermek igen nagyfokú bizonytalanságban nő fel, ami a saját jövőbeni szerepeit illeti. ${ }^{23}$

Az egyes életkorokban a gyerekek eltérő tüneteket produkálhatnak, attól függően, hogy hány évesen bomlik fel a családjuk. Természetesen a személyiségük fejlettségének, érettségének is jelentősége van. Fontos tudni, hogy a következőkben felsorolt káros hatások jelentősen mérsékelhetők vagy teljesen ki is küszöbölhetők, amennyiben a szülők egymással, illetve a különélő szülőnek a gyermekkel való kapcsolata a válást követően is harmonikus marad, valamint ha a gyermek számára elérhetőek az úgynevezett protektív faktorok, azaz egy kedves, gondoskodó nagyszülő, egy megbízható barát vagy egy hűséges kutya, akik segíthetnek a gyermeknek a trauma feldolgozásában. ${ }^{24}$

A gyermek hároméves koráig viszonylag könnyen alkalmazkodik a megváltozott körülményekhez, viszont ezen időszakban a legnagyobb a veszélye annak, hogy ha a másik szülő kikerül a látóköréből, akkor akár teljesen el is felejtheti, nem alakul ki közöttük a kötődés. Ebben az életkorban érdemes különösen odafigyelni arra, hogy a gyermek gyakran, kb. 2-3 naponta találkozzon a különélő szülővel. A nagyon kicsi gyermekkel magára maradó anya kiemelt odafigyelést igényel, esetükben könnyen alakulhat ki depresszió, amely a gyermekre is rossz hatással lehet. Ha egy nő újszülött gyermekével marad egyedül, bánatát, csalódottságát és kétségbeesését óhatatlanul közvetíteni fogja gyermeke felé is, azaz nem tud biztonságos, szeretetteljes légkört biztosítani számára, ennek következtében a gyermek magatartásában zavarok jelentkezhetnek. ${ }^{25}$

Az óvodáskorú gyermekek esetében sokszor regressziót figyelhetünk meg, azaz fejlődésük visszaeshet egy korábbi szakaszba, például a korábban szobatiszta gyermek újra bepisil, nem képes a korábbi színvonalon beszélni vagy „elfelejt” késsel-villával enni, pohárból inni. ${ }^{26}$ Tipikus az is, hogy fokozott ragaszkodást mutatnak a szülő iránt, a szeparációs szorongásuk miatt szinte lehetetlen bárhol is ott hagyni őket, sok esetben az elalvás is megnehezedik. Ennek oka, hogy attól tartanak a gondozó szülő is

\footnotetext{
Ranschburg (2012) 123.

Zimbardo-Coulombe (2015) 15.

Largo-Czernin (2011) 175.

Ranschburg (2012) 167.

Ranschburg (2012) 163.
} 
egyik pillanatról a másikra eltűnik majd az életükből, és ők ott maradnak egyedül. ${ }^{27}$ További gyakori tünetek: a depresszió, az ágybavizelés, hosszú távon a tartós önvád, valamint a csökkenő önbizalom. ${ }^{28} \mathrm{Az}$ egocentrikus világképük miatt a gyerekek gyakran saját magukat hibáztatják a szülők kapcsolatának megromlásában. Ez az önvád és bủntudat sokszor felnőttkorban is megmarad és az élet számtalan területére áttevődik. ${ }^{29}$

A kisiskolás gyermekek általában szomorúsággal, rosszkedvvel, súlyosabb esetben depresszióval reagálnak a szülők válására. Az iskolában koncentrációs zavarok, teljesítményromlás, dadogás, tikkelés, körömrágás is jelentkezhet, ezen tünetek mind erős szorongásra utalnak. ${ }^{30}$ Nehéz helyzetben vannak azok, akik hétéves kor körül szembesülnek a válással, hiszen az iskolakezdés önmagában is nagy változást jelent a gyermek életében, ehhez is nehéz alkalmazkodnia. Tipikusan erre az életkorra jellemző, hogy szívesen fantáziálnak a szülők újraegyesítéséről, egyáltalán nem véve tudomást a tényekről és a valós helyzetről. Akkor is bíznak abban, hogy a szülők egyszer újra egymásba szeretnek és együtt lesznek, ha már mindkettőnek új párkapcsolata van (lásd: Erich Kästner: A két Lotti). ${ }^{31}$

A 9-12 éves kiskamaszok legtöbbször igen hevesen reagálnak a család felbomlására. Intenzív haragot éreznek mindkét szülővel szemben, egyúttal egyfajta szégyenérzet is úrrá lesz rajtuk. Sok esetben lojalitáskonfliktusba keverednek, főleg akkor, ha a szülők választásra kényszerítik őket. A kamaszkorban természetesen jelentkező testi/lelki változások közepette a gyermekek eleve egy válsághelyzetben vannak, nagyon sokat ronthat ezen, ha a szülők éppen ekkor döntenek a válás mellett. ${ }^{32}$ Identitásproblémák is kialakulhatnak, hiszen ebben az életszakaszban kellene elindulnia a szülőkről való leválási folyamatnak, és el kellene kezdődnie a személyiség, az identitás megszilárdulásának, ezt egy ilyen válsághelyzet nagyon meg tudja zavarni, a gyermek vagy kénytelen lesz nagyon gyorsan leválni, úgy hogy erre valójában még nem érett meg, vagy hosszú időre „beleszorul” a gyermek szerepbe. Hosszú távon alacsony önértékelés és depreszszió is kialakulhat.

További jellemző tünetek:

- romló iskolai teljesítmény;

- koncentrációs nehézségek;

- elszigetelődés;

- hangulata, viselkedése megváltozik;

- feszült;

- fegyelmezetlen. ${ }^{33}$

\footnotetext{
Largo-Czernin (2011) 23.

Bognár-Telkes (1986) 97.

Dowling-Barnes (2001) 30.

Cziegler (2010) 43.

Bognár-Telkes (1986) 97-98.

Largo-Czernin (2011) 52.

Bognár-Telkes (1986) 98-99.
} 
A 13-18 éves fiatalok már kicsit tárgyilagosabban, racionálisabban tudják szemlélni szüleik kapcsolatának válságát, főleg abban az esetben, ha beleláttak annak árnyoldalaiba, és pontosan tudják, hogy mi vezetett el a jelenlegi helyzet kialakulásáig. Ennek ellenére nagyfokú kiábrándultságot élhetnek át, illetve komolyan aggódhatnak a saját jövőjük miatt. A válsághelyzet hatására túl korán bonyolódhatnak kritikátlanul éretlen szexuális kapcsolatokba, amelynek következtében később is nehézségekkel fognak küzdeni a párkapcsolatok terén.

Jellemző tüneteik:

- harag;

- szomorúság;

- gátlásosság;

- nyugtalanság. ${ }^{34}$

\section{A válás lélektani hatásai a szülökre nézve}

A szülők számára a kapcsolat megszűnése legtöbbször egyszerre jelent megkönnyebbülést és veszteséget. ${ }^{35}$ Fontos lenne, hogy az emberek hagyjanak időt maguknak, ne próbáljanak meg azonnal továbblépni, új kapcsolatba bonyolódni, mert az elvesztett kapcsolatot ugyanúgy meg kell gyászolni, a veszteséget ugyanúgy fel kell dolgozni, mint egy haláleset során. Kiemelkedő jelentősége van annak, hogy a gyermekkel maradó szülő miként dolgozza fel a másik szülő elvesztését, még abban az esetben is, ha ő maga kezdeményezte az elszakadást. A szomorúság, a magányosság érzése és az indulatok mind-mind áttevődnek a gyermekre, akinek ez a személyiségfejlődésében komoly károkat okozhat. ${ }^{36}$ Sokan érzik magukat ebben az időszakban zaklatottnak, feszültnek, bosszúsnak és idegesnek. További jellemző érzelmek: düh, csalódottság, gyűlölet, kétségbeesés. Ezen erősen negatív érzéseknek azért kell hamar gátat szabni, mert ezek a gyermek számára nagyon fenyegetőek. ${ }^{37}$

Ha a magányosság érzése elhatalmasodik az emberen, képes egészen kilátástalannak ítélni a helyzetét, ami könnyen torkollhat depresszióba, illetve elsősorban a férfiak esetében vezethet öngyilkossághoz. ${ }^{38}$ Kiemelkedő jelentősége van annak, hogy az a szülő, aki a gyermekkel marad, milyen segítséget kap a továbblépéshez, illetve a gyermekneveléshez. Az a szülő, aki ebben a helyzetben úgy érzi, teljesen egyedül maradt, senki sincs, aki róla gondoskodik, nagy valószínűséggel maga sem lesz képes kiegyensúlyozottan gondoskodni a gyermekéről. ${ }^{39}$ Nehezen fogja a gyermek jól érezni magát, ha a szülő sem érzi jól magát. ${ }^{40}$

\footnotetext{
Bognár-Telkes (1986) 100.

Bognár-Telkes (1986) 53.

Ranschburg (2012) 166.

Largo-Czernin (2011) 148-149.

Zimbardo-Coulombe (2015) 93.

Zimbardo-Coulombe (2015) 89.

Largo-Czernin (2011) 14.
} 
Érdemes különbséget tenni az elhagyó és az elhagyott között. Míg utóbbi számára a válás hatalmas csalódást okoz, és önbizalomcsökkenése miatt hosszú ideig nem lesz képes megbízni az ellenkező nem képviselőiben, addig az előbbi elsősorban lelkiismeretfurdalással küszködik, és ennek csökkentése érdekben időnként egészen méltánytalan megállapodásokba is hajlandó belemenni, azaz például minden vagyont ott hagy az elhagyott félnél.

A legtöbb szülő ebben a helyzetben nagyfokú bűntudatot érez, és aggódik a válás gyermekre gyakorolt hatása miatt. Azt nagyjából mindenki tudja, hogy a család felbomlása rossz hatással van a gyermekre, sokan éppen emiatt halogatják a végsőkig a döntés meghozatalát. Azt azonban már kevesebben tudják, hogy mi az, ami segítséget nyújthat minden érintettnek, illetve azt is inkább csak sejtik - bár be nem tartják -, hogy melyek azok a dolgok, amelyeket mindenképpen el kell kerülni a válás alatt és után is. Maga a válási folyamat, illetve az azt követő újjáépítési szakasz mindenki számára rendkívül megterhelő, nagyon stresszes és sok szorongással jár együtt, még akkor is, ha a felek viszonylag békésen rendezik a viszonyaikat. Azok, akik ezekkel a terhekkel nehezen birkóznak meg, sokáig nem tudnak majd új életet kezdeni. A megküzdési startégiáink eltérő mértékben fejlettek, és aki nem a legjobb megoldást választja, könnyen elindulhat a lejtőn. A szorongás oldására gyakran alkalmazzák a cigarettát, az alkoholt, esetleg nyugtatókat, egyéb gyógyszereket és drogokat, amelyek hosszú távú káros hatásai mindenki számára ismertek. Azoknál, akik nem tudnak kilábalni a helyzetből különféle pszichiátriai betegségek is kialakulhatnak, úgymint alkoholizmus, depresszió, szorongásos zavarok, de különféle balesetekbe is keveredhetnek, illetve a nagyfokú stressznek köszönhetően szívinfarktus, gyomorvérzés alakulhat ki. ${ }^{41}$

Tovább nehezíti a helyzetet, ha valamelyik fél elköltözik a közös otthonból, és egyéb lehetőség híján visszaköltözik a szüleihez. Ennek során nemcsak a megszokott életszínvonalat kell feladnia, hanem akár egész „felnőttségét” is, hiszen ezáltal újra gyerekszerepbe kényszerül, ismét alkalmazkodnia kell szülei elvárásaihoz.

A magára maradt szülő sokszor megpróbál egyedül helyt állni, és egyszerre eleget tenni az apai és az anyai szerep elvárásainak. Tekintettel arra, hogy a gyermek életében az anyának és az apának eltérő feladatai vannak, ez igen emberpróbáló feladat. Elsősorban az anyákra jellemző, hogy a válás okozta csalódásból hosszú ideig nem tudnak kilábalni, a gyászfolyamat évekig elhúzódik, és a gyermek válik életük egyetlen értelmévé. A legnagyobb hiba, amit a „mártír anyák” elkövethetnek, hogy túlóvják, túlféltik, túlkímélik a gyermekeiket, nem engedik, hogy hibát kövessenek el, vagy kockázatot vállaljanak, így felnőve nehezen boldogulnak majd a világban és társas kapcsolataikban. ${ }^{42}$

\footnotetext{
41 Bognár-Telkes (1986) 61.

42 Zimbardo-Coulombe (2015) 118.
} 


\section{A válás utóhatásai}

Azokban a felbomló kapcsolatokban, ahol a párnak közös gyermeke is van, a szülői felügyelet rendezése a leghevesebb viták és csatározások színtere, aminek következményei - akár egy egész életre kiható módon - a gyermeken csapódnak le. A kapcsolat megszűnése után, ha nem sikerült a békés elválás, legtöbbször nem múködik gördülékenyen a kapcsolattartás sem.

A szülők számtalan hibát követnek el ebben az időszakban, amellyel elsősorban nem egymásnak, hanem a gyermeküknek ártanak. A legtipikusabb és egyúttal legnagyobb hiba, amit egy szülő elkövethet, ha rendszeresen akadályozza a kapcsolattartást, és közben igyekszik mindenáron befeketíteni a másik szülőt a gyermek előtt. Pedig nagyon fontos lenne, hogy a szülők a család felbomlása után is képesek legyenek békésen együttmúködni egymással, mert a gyermek számára ez a kapcsolat jelenti a párkapcsolati alapmintázatot, azaz az ő jövőbeni szerelmi kapcsolatainak minőségét, stabilitását, tartósságát is alapjaiban határozza meg. Szintén érdemes elkerülni a gyermek állásfoglalásra kényszerítését. Valóban érdemes megkérdezni, hogy mit szeretne, illetve azt is joga van elmondani, hogy ő miként látja a kialakult helyzetet, de soha nem szabad olyan döntés meghozatalát várni tőle, illetve olyan választás elé állítani, amelyben nem képes állást foglalni, nem szabad tehát érzelmileg túlterhelni, mert ennek hatásai a személyiségfejlődésben is jelentkezni fognak.

\section{A szülői elidegenítési szindróma (PAS)}

A Richard Gardner amerikai pszichiáter által leírt szülői elidegenítési szindrómának (Parental Alienation Syndrome) nevezett tünetegyüttes megítélése régóta vitatott, a pszichológusok sem Magyarországon, sem külföldön nem tudnak egységes álláspontra helyezkedni létezésével, illetve megjelenésével kapcsolatban. Tünetei mindenesetre elég jellemzőnek tűnnek, és akik gyakran találkoznak különélő szülőkkel meglepően sokszor találkozhatnak vele. A lényege, hogy a gyermekkel együtt élő szülő igyekszik mindent elkövetni annak érdekében, hogy a közös gyermekük elutasítsa a különélő szülőt és annak egész családját. Ezt legtöbbször hamis történetek mesélésével, a gyermek megtévesztésével, a másik szülő és annak családja állandó befeketítésével éri el.

A gyakori „agymosás” következtében a gyermek emlékezetéből eltűnnek a másik szülővel kapcsolatos személyes élményei és az elidegenítő szülő által mesélt „rémtörténetekkel" helyettesítődnek. ${ }^{43}$ Azt, hogy a gyermek a gondozó szülő pártjára álljon, viszonylag könnyű elérni, hiszen amiatti félelmében, hogy elveszíti a szülő szeretetét és teljesen egyedül marad, képes bármit elhinni és bármit elfogadni. A gyermek erősen függ a gondozó szülőtől, és tudja, hogy csak rá számíthat. Ily módon könnyedén rá lehet venni arra is, hogy a különélő szülőt a továbbiakban a keresztnevén szólítsa, új partnerét pedig nevezze apának/anyának még abban az esetben is, ha e személyek gyakran

43 Baker-Fine (2017) 42. 
cserélődnek. ${ }^{44}$ Tipikus tünete - és éppen ezért olyan nehéz a felismerése -, hogy a gyermek azt állítja, saját döntése, hogy nem kíván a másik szülőjével kapcsolatot tartani. ${ }^{45}$ Néhány jellemzője alapján azonban könnyedén felismerhetjük: a gyermek a különélő szülőről nagyon negatív véleménnyel van, szerinte csak rossz tulajdonságai vannak, egyáltalán nem kötődik hozzá, sok esetben kimondottan utálja. Azonban, ha rákérdezünk, hogy mi ennek az oka, általában nem képes megindokolni, vagy olyan indokokat sorol fel, amelyek irrelevánsak a gyermek szempontjából, illetve egyértelmű, hogy ez nem a saját véleménye, például azt mondja, azért utálom az apámat, mert elkártyázta a házunkat, vagy mert megcsalta az anyámat, amelyből egyenesen következik, hogy engem is elhagyott.

Fontosnak tartom kiemelni a szülők együttmúködési kötelezettsége körében, hogy ezt a mindennapi élet egyszerű elvárásai szintjén is be kell tartani. Azaz - a gyermek érdekében - abban is alkalmazkodniuk kell egymáshoz, hogy nehogy a fiatallal szemben egymásnak ellentmondó elvárásokat támasszanak, ellentétes utasításokat tegyenek, egyúttal az érzelmi zsarolástól is tartózkodni kell.

\section{Következtetések}

Az eddig bemutatott elemzésből világosan láthatjuk, hogy a válás elsősorban nem jogi, hanem érzelmi folyamat, annak minden negatív következményével együtt. Komoly hiba tehát, hogy ezeket az élethelyzeteket kizárólag a jog eszközeivel próbáljuk megoldani. Az érzelmeket, indulatokat nem lehet jogszabályokkal kordában tartani, mégis nagyon sokan nem tudják, hogy kihez fordulhatnának segítségért. A legtöbb szülő azt hiszi, hogy ha már nem bírják tovább együtt, akkor el kell menni az ügyvédhez, majd a bíróságra, és a jogászok mindent megoldanak. És valóban előbb-utóbb születni fog egy ítélet, amely valószínűleg egyiküknek sem fog tetszeni, és a benne foglaltakat nem fogják betartani, hiszen annak meghozatala során senki sem volt tekintettel a szülők és a gyermekek „lelkére”.

A legjobb megoldás a kapcsolat megszűnése során a mediáció, illetve a válási terápia igénybevétele, ahol elsősorban a konfliktus feloldására, a kommunikáció és a bizalom helyreállítására koncentrálnak, csak ezt követik a jogi kérdések - úgymint szülői felügyelet, vagyon megosztása, lakáshasználat - rendezése. Az alternatív vitarendezésnek és a terápiának nem az a célja, hogy a felek újra egymásba szeressenek (bár mellékhatásképpen ez sem rossz), hanem hogy a kapcsolatuk megszűnését követően képesek legyenek egymással együttmúködni a közös gyermekük érdekében. Ez mindannyiunk, az egész társadalom érdeke, hiszen csak így biztosíthatunk a gyermekek számára olyan gyermekkort, amelyet megérdemelnek: nyugalmat, békességet, biztonságot. Akkor és ott, hiszen a gyermekkor egyszeri és megismételhetetlen. ${ }^{46}$

\footnotetext{
Baker-Fine (2016) 14.

Largo-Czernin (2011) 178-180.

6 Gyurkó (2015) 52.
} 


\section{IRODALOMJEGYZÉK}

Bagdy Emőke - Kalo Jenő - Popper Péter - Ranschburg Jenő (2007): A család: harcmező és békesziget. Budapest, Saxum Kiadó.

Baker, Amy - Fine, Paul (2016): A szülooi elidegenítésről. Budapest, Kalliopé.

Baker, Amy - Fine, Paul (2017): Extelen döntések. Budapest, L’Harmattan.

Bognár Gábor - Telkes József (1986): A válás lélektana. Budapest, KJK.

Cziegler Orsolya (2010): Egyedül nevelem. Budapest, Saxum Kiadó.

Dowling, Emilia - Barnes, Gill Gorell (2001): Együttmüködés a gyermekekkel és szüleikkel a különélés és a válás során. Budapest, Coincidencia.

Figdor, Helmuth (1996): A reménység peremén, elvált szülök gyermekei. Budapest, Fekete Sas Kiadó.

Fischer Eszter (2005): Modern mostohák. Budapest, Saxum Kiadó.

Földházi Erzsébet (2009): Válás. In: Demográfiai Portré. Budapest, KSH Népességtudományi Kutató Intézet.

Gyurkó Szilvia (2015): Rám is gondoljatok. Budapest, Bookline.

Largo, Remo H. - Czernin, Monika (2011): Válás után boldog gyerekek?. Budapest, Park Kiadó.

Ranschburg Jenő (2005): Egy egész életre szóló találkozás. In Popper Péter - Ranschburg Jenő - Vekerdy Tamás: Sorsdöntő találkozások: szülők és gyermekek. Budapest, Saxum Kiadó.

Ranschburg Jenő (2012): Családi kör. Budapest, Saxum Kiadó.

Somlai Péter (2013): Család 2.0. Budapest, Napvilág Kiadó.

Visontai-Szabó Katalin - Zakar András (2014): A családok kialakulása és felbomlása napjainkban. Forum Acta Juridica et Politica, 4. évf. 1. sz. 275-290.

Zimbardo, Philip - Coulombe, Nikita D. (2015): Nincs kapcsolat. Budapest, Libri Kiadó.

\section{ABSTRACT}

\section{Psychological Processes and Consequences during the Dissolution of the Parents' Relationship}

VISONTAI-SZABÓ Katalin

Families have been undergoing numerous changes recently. In the last few decades fewer and fewer couples get married and nowadays every other marriage ends in divorce. Primarily, it is a problem because of the negative psychological impact children are affected by. Another tendency is to live alone or live apart together, which forms of living make a negative effect on childbearing. As it is a huge problem affecting the whole society, it would be very useful to create and establish a support service, through which parents would receive legal and psychological assistance for the resolution of their conflicts and to cope with the loss, in order to facilitate future cooperation. Couple's therapy and mediation would be accessible to anyone as part of the service.

Keywords: divorce, child custody decisions, visitation, psychology, parental alienation, single parent family, patchwork family, rights of the child 